\title{
21. CRETACEOUS AND PALEOGENE CALCISPHAERULIDAE FROM DSDP LEG 40, SOUTHEASTERN ATLANTIC
}

\author{
Hans M. Bolli, Department of Geology, Swiss Federal Institute of Technology, Zürich,
} and University of Zürich, Switzerland

\section{INTRODUCTION}

Isolated Calcisphaerulidae from DSDP sections have previously been reported from the Indian Ocean Leg 27, from which Jurassic, Lower and Upper Cretaceous species were described and illustrated by the SEM method (Bolli, 1974), and from the Antarctic Leg 35, where for the first time Paleocene species were described and illustrated by Rögl (1976).

Of the six sites drilled during Leg 40, Calcisphaerulidae were present in Sites 361, 363, and 364 (Figure 1). Only rare and poorly preserved specimens (Pithonella ? sphaerica) were obtained from the Cape Basin Site 361, where they occur in the Lower Cretaceous sapropels from Core 32 down.

Calcisphaerulidae are much more frequent and better preserved in the Lower Cretaceous Cores 26 to 39 of the Walvis Ridge Site 363 . In this site they are present, though only rare, in the Upper Cretaceous (Samples 182, $42-44 \mathrm{~cm}$ to Core 22) and in the Paleocene (Samples $18-1,52-54 \mathrm{~cm}$ to $18-2,34-38 \mathrm{~cm}$ ).

Rare Calcisphaerulidae of Pithonella sphaerica aspect occur in the Coniacian-Santonian Core 19 of Site 364 in the Angola Basin.

Attention in this report is focussed entirely on the Site 363 Calcisphaerulidae which are described and illustrated in some detail, and whose stratigraphic distribution and significance is discussed.

The specimens illustrated on Plates 1-7 are deposited in the Museum of Natural History, Basel, Switzerland, under the numbers C 33949 to C 33990 . The number for each specimen appears with the species explanations for the plates.

\section{STRATIGRAPHIC DISTRIBUTION OF THE CALCISPHAERULIDAE AT SITE 363}

Three distinct and stratigraphically restricted groups of species occur at Site 363 (Figure 2):

1) The two spherically shaped species Pithonella cf. bollii and $P$. titanoplax are restricted to the lower Paleocene. These species were described first from sediments of the same age from the Antarctic Site 323 by Rögl (1976).

2) The oval-shaped Pithonella cooki and the more elongate $P$. krasheninnikovi seem closely related by morphologically intermediate forms. P. krasheninnikovi is recorded from the Campanian to middle Maestrichtian, $P$. cooki throughout the Maestrichtian. The two

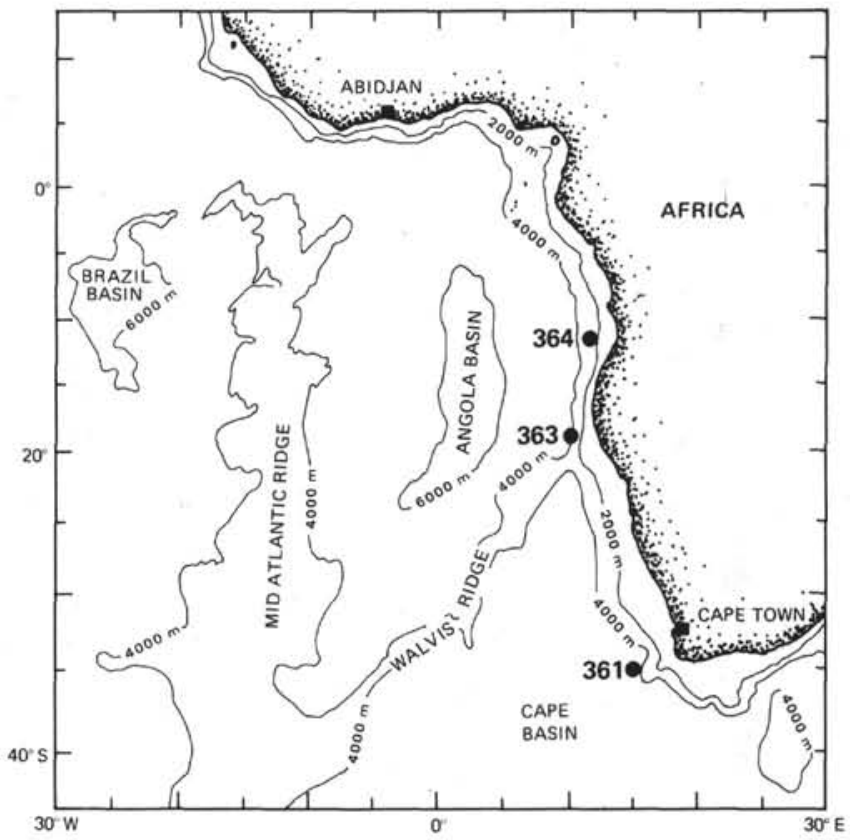

Figure 1. Location of Leg 40 Sites 361, 363, and 364.

layers forming the test of the lower Paleocene $P$. titanoplax are similar to those of $P$. cooki and $P$. krasheninnikovi. Should the three species represent an evolutionary lineage, the trend would be from the strongly elongate $P$. krasheninnikovi via the ovalshaped $P$. cooki to the spherical $P$. titanoplax. Such a trend can be followed in Cores 22 to 18 of Site 363 (see Figure 2).

Because of dissolution, intermittent coring (Cores 2325) and a Cenomanian-Turonian hiatus, Cenomanian to lower Campanian Calcisphaerulidae are absent at Site 363.

3) Mostly very rich assemblages occur in the Albian to upper Aptian Cores 26-39. They are dominated by spherical forms here included in Pithonella cf. sphaerica, which occurs throughout the cored Lower Cretaceous interval. Much less frequent are smaller oval-shaped forms here placed in $P$. cf. ovalis. They occur in Cores 26-34. The characteristic Bonetocardiella cf. conoidea are frequent in Cores 27 and 28 , and continue in lesser numbers down to Core 32. Both $P$. ovalis and $B$. conoidea are restricted to the upper Albian of Site 363. 


\begin{tabular}{|c|c|c|c|c|c|c|c|c|c|}
\hline $\begin{array}{c}\text { AGE } \\
\text { based on calcareous } \\
\text { Nannoplankton }\end{array}$ & $\begin{array}{c}\text { DEPTH BELOW } \\
\text { SEA FLOOR } \\
(\mathrm{m})\end{array}$ & 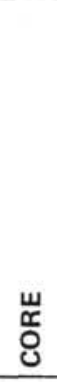 & 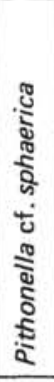 & 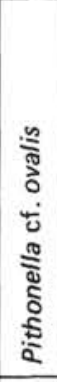 & 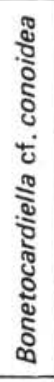 & 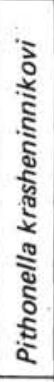 & 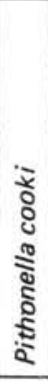 & 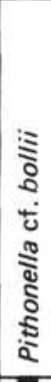 & 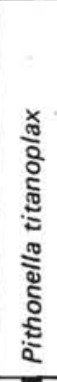 \\
\hline LOWER PALEOCENE & $325.5 \cdot 335$ & 18 & & & & & & U & \\
\hline \multirow{3}{*}{ MAESTRICHTIAN } & $335-344.5$ & 19 & & & & & & & \\
\hline & $344.5-354$ & 20 & & & & & & & \\
\hline & $363.5-373$ & 21 & & & & & $\bar{\square}$ & & \\
\hline \multirow[t]{4}{*}{ CAMPANIAN } & $373-382.5$ & 22 & & & & - & & & \\
\hline & $382.5-392$ & 23 & & & & & & & \\
\hline & $401.5-411$ & 24 & & & & & & & \\
\hline & $420.5-430$ & 25 & & & & & & & \\
\hline \multirow{9}{*}{ UPPER ALBIAN } & $439.5-449$ & 26 & & & & & & & \\
\hline & $458.5-469$ & 27 & & & & & & & \\
\hline & $477.5-487$ & 28 & & & & & & & \\
\hline & $496.5-506$ & 29 & & & & & & & \\
\hline & $515.5-525$ & 30 & & & & & & & \\
\hline & $534.5-544$ & 31 & & & & & & & \\
\hline & $553.5-563$ & 32 & & & & & & & \\
\hline & $572.5-582$ & 33 & & & & & & & \\
\hline & $591.5-601$ & 34 & & & & & & & \\
\hline \multirow{4}{*}{$\begin{array}{c}\text { MIDDLE - LOWER } \\
\text { ALBIAN }\end{array}$} & $610.5 \cdot 620$ & 35 & & & & & & & \\
\hline & $629.5 \cdot 639$ & 36 & & & & & & & \\
\hline & $648.5-658$ & 37 & & & & & & & \\
\hline & $667.5-677$ & 38 & & & & & & & \\
\hline \multirow[b]{2}{*}{ UPPER APTIAN } & $686.7-696$ & 39 & & & & & & & \\
\hline & $705.5-715$ & 40 & & & & & & & \\
\hline
\end{tabular}

Figure 2. Distribution of Calcisphaerulidae in Leg 40 Site 363. 
List of Leg 40 Samples Investigated In Which Calcisphaerulidae Occur

\begin{tabular}{ll}
\hline Site 361 & Site 363 (Cont) \\
$32, \mathrm{CC}$ & $29-1,71-73$ \\
$48, \mathrm{CC}$ & $29-4,131-133$ \\
& $30-1,38-40$ \\
Site 363 & $31-4,119-121$ \\
$18-1,52-54$ & $32-1,125-127$ \\
$18-1,70-72$ & $32-4,72-78$ \\
$18-1,98-100$ & $32, \mathrm{CC}$ \\
$18-1,143-145$ & $33-2,46-48$ \\
$18-2,34-38$ & $33-4,85-87$ \\
$18-2,42-44$ & $34-1,116-118$ \\
$18-2,136-138$ & $36-1,74-76$ \\
$19-2,58-60$ & $37-4,71-73$ \\
$20-1,58-60$ & $37, \mathrm{CC}$ \\
$21-1,58-60$ & $38-1,73-75$ \\
$21-4,8-10$ & $39-2,92-94$ \\
$22-1,77-79$ & Site 364 \\
26, CC & $19-1,58-60$ \\
$27-1,44-46$ & $19-2,58-60$ \\
27, CC & \\
$28-1,107-109$ & \\
\hline
\end{tabular}

\section{SYSTEMATIC TREATMENT OF CALCISPHAERULIDAE}

Reference is made to Bolli (1974) where a general discussion of the Family Calcisphaerulidae and a table of families, genera, and species (published up to 1972) is presented. Of the 12 genera published up to that date, 8 were placed in synonymy with Pithonella Lorenz, 1901. One species recognized in Leg 40 is assigned to Bonetocardiella Dufour (1968). The other six species are included in the genus Pithonella. All taxa described and illustrated in this paper are either identical with or similar to previously known species.

\section{SYSTEMATIC DESCRIPTION}

\section{Family CALCISPHAERULIDAE Bonet, 1956}

\section{Genus PITHONELLA Lorenz, 1901}

Reference is made to Bolli (1974, p. 852) for the genus description. The known stratigraphic distribution of the genus which was cited in that publication as "Jurassic, predominantly Upper; Lower and Upper Cretaceous," is here extended into the lower Paleocene.

\section{Pithonella cf. bollii Rögl (1976)}

(Plate 1, Figures 1-6)

The specimens are similar to those originally described by Rögl (1976, p. 701, Plate 1, Figures 1-4, Plate 2, Figures 1-4) from the Antarctic Leg 35 Site 323. The average size of about $60 \mu \mathrm{m}$ is about the same. The aperture in the Site 323 specimens is given as extremely large and circular, but in the Site 363 specimens ranges from nonexistent (Plate 1, Figure 1) to very small (Plate 1, Figure 3) to fairly large and circular (Plate 1, Figure 4). The wall is formed by two layers of calcite crystals which are about equal in thickness in the Site 323 specimens. In contrast at Site 363, the thickness of the inner layer appears slightly less than that of the outer one. Further, the surface of the loosely arranged rhombohedral crystals of the outer layer are fairly strongly corroded in the Site 363 specimens (Plate 1, Figures 2, 6). As in the Site 323 specimens, the inner layer is formed by slender and tightly packed crystals with the rhombohedrons extended along the $c$-axis and arranged perpendicular to the surface.

Both the Site 323 and the Site 363 specimens occur in the lower part of the lower Paleocene.
Recorded occurrence: DSDP Site 363, Walvis Ridge, Southeastern Atlantic. Samples $18-1,52 \mathrm{~cm}$ to $18-2,38 \mathrm{~cm}$. Rare.

Age: Lower Paleocene, based on calcareous nannoplankton and on planktonic foraminifers (Cruciplacolithus tenuis Zone, Globorotalia pseudobulloides Zone).

\section{Pithonella titanoplax Rögl (1976)}

(Plate 1, Figures 7-12)

1976 Pithonella titanoplax Rögl, p. 701, pl. 1, fig. 5-9, pl. 2, fig. 5-8.

The specimens from Site 363 appear to be identical with those originally described by Rögl (1976) from the Antarctic Leg 35 Site 323 . They have a similar average size of $60-70 \mu \mathrm{m}$, similar very large, circular apertures, and have two layers of calcite crystals of approximately the same thickness forming the test. As in Pithonella bollii the inner layer is formed by tightly interlocked rhombohedrons elongate along the $\mathrm{c}$-axis which lie perpendicular to the surface. In contrast to $P$. bollii, the crystals of the outer layer are of tabular shape and positioned with one of the long, narrow faces on the inner layer. They are fairly loosely arranged in an irregular criss-cross pattern which is clearly seen in Plate 1, Figure 9. Outer layer crystals having a similar shape and arrangement also characterize the Upper Cretaceous $P$. cooki and $P$. krasheninnikovi (Plates 2 and 3). The specimen in Plate 1, Figure 10, with the enlarged surface shown in Plate 1, Figure 12, possesses outer layer crystals that are more stubby and less elongate, as is also the case in $P$. cooki. Both the very close morphology as well as stratigraphic restriction to the lower part of the lower Paleocene justify the inclusion of the Site 363 specimens into $P$. titanoplax.

Recorded occurrence: DSDP Site 363, Walvis Ridge, Southeastern Atlantic. Samples 18-1, $52 \mathrm{~cm}$ to $18-2,38 \mathrm{~cm}$. Rare.

Age: Lower Paleocene, based on calcareous nannoplankton and on planktonic foraminifers (Cruciplacolithus tenuis Zone, Globorotalia pseudobulloides Zone).

\section{Pithonella cooki Bolli}

(Plate 2, Figures 1-12)

1974 Pithonella cooki Bolli, p. 856, pl. 6, fig. 9-12, pl. 18, fig. 3-9, pl. 23, fig. 6 .

The specimens of Site 363 compare very well with those originally described from the Eastern Indian Ocean Leg 27 Site 260. The specimens, which have an average size of $70-80 \mu \mathrm{m}$ and consist of two layers of calcite crystals, vary in shape from only slightly elongate (Plate 2, Figure 1) to more distinctly elongate, forms (Plate 2, Figure i1) that are, respectively, transitional to and resemble very strongly Pithonella krasheninnikovi. The inner layer of Site 363 specimens is formed by fairly large rhombohedral crystals with their c-axis perpendicular to the test surface. Crystals and part of the inner layer are clearly visible on Plate 2, Figures 4, 7, 8, and 12. As in Pithonella titanoplax, the outer layer consists of loosely arranged tabular crystals.

A probable Coniacian to Santonian age was assigned to the Indian Ocean Site $260 P$. cooki, based on the youngest elements (Globotruncana lapparenti group) of a heterogeneous planktonic foraminiferal fauna. However, the possibility was left open that these youngest faunal elements could also be reworked; thus the $P$. cooki specimens could still be younger. Based on planktonic foraminifers and calcareous nannoplankton occurring together with the calcisphaerulids, the Site $363 P$. cooki are definitely Maestrichtian. Whether they range further down stratigraphically could not be evaluated at this site because calcareous microfossils of Core 22 are already strongly affected by dissolution (see description below of Pithonella krasheninnikovi and specimens of that species on Plate 3, Figures 8-12). Calcareous nannofossils are totally absent in Cores 2225 , and reappear only in the Albian Core 26.

Recorded occurrence: DSDP Site 363, Walvis Ridge, Eastern South Atlantic, Samples $18-2,136 \mathrm{~cm}$ to $21-1,60 \mathrm{~cm}$. Infrequent.

Age: Maestrichtian, on calcareous nannoplankton and on planktonic foraminifers (Arkhangelskiella cymbiformis to Micula mura Zone, Globotruncana havanensis to Globotruncana mayaroensis Zone).

\section{Pithonella krasheninnikovi Bolli}

(Plate 3, Figures 1-12)

1974 Pithonella krasheninnikovi Bolli, p. 856, pl. 7, fig. 1-5, pl. 18, fig. $10-12$, pl. 19 , fig. $1-12$, pl. 20 , fig. $1-4$, pl. 24 , fig. $1-2$. 
The Site 363 specimens are identical with those originally described from the Eastern Indian Ocean Leg 27 Site 260. The specimens have an average length of about $110 \mu \mathrm{m}$ and a width of about $60 \mu \mathrm{m}$. As in Pithonella cooki, a subcircular aperture in terminal position is generally present (Plate 3, Figures $5,10,11$ ). In some specimens (Plate 3, Figures 2, 4) it is slightly offset from the longitudinal axis and appears rather elliptical. In others (Plate 3, Figure 1) the aperture is not apparent.

Two layers form the test, an inner one of large rhombohedral crystals (Plate 3, Figures 6,7 ) and an outer one with smaller tabular crystals (Plate 3 , Figures $3,6,7$ ), both the same as in $P$. cooki. While the specimens are mostly well preserved in Core 21 , with the outer layer of tabular crystals intact (Plate 3, Figures 1-7), those of Core 22 have only the coarse inner layer preserved (Plate 3, Figures 8-12). A specimen which shows partial dissolution of the outer layer crystals is shown in Plate 3, Figure 5. On Plate 3, Figure 6, a detail of Figure 5, large inner layer crystals begin to show through the loosely arranged and partially dissolved small outer layer crystals.

A coccolith fragment, partially embedded in a large crystal of the inner layer, is visible on Plate 3, Figure 9 (detail of Plate 3, Figure 8) just below the center of the photograph and to the right of a small rhombohedral crystal.

For the same reasons as for Pithonella cooki (see description above of that species), a probable Coniacian to Santonian age was originally assigned to $P$. krasheninnikovi. Comparison with calcareous nannoplankton and planktonic foraminifers at Site 363, Cores 20-22, shows that the species here is of Campanian to lowermiddle Maestrichtian age.

Recorded occurrences: DSDP Site 363, Walvis Ridge, Eastern South Atlantic, Samples $20-1,58 \mathrm{~cm}$ to $22-1,79 \mathrm{~cm}$. Infrequent.

Age: Campanian to lower-middle Maestrichtian, on calcareous nannoplankton and on planktonic foraminifers (Tetralithus trifidus to Arkhangelskiella cymbiformis Zone, Globotruncana calcarata to Globotruncana havanensis Zone).

\section{Pithonella cf. ovalis (Kaufmann) \\ (Plate 4, Figures 1-6)}

Because of their shape, the comparatively small oval specimens are here tentatively included in Pithonella ovalis which was originally described by Kaufmann (in Heer, 1865) from the type locality of the Cenomanian to Coniacian Seewerkalk of central Switzerland. In all probability they come from the Coniacian part of that sequence. Those present at Site 363 are Albian in age. It is possible that the Cenomanian-Coniacian forms are directly related to those occurring in the Albian. To confirm this, however, SEM studies on suitable material in continuous sections are required.

It appears that the outer surface of the investigated Site 363 specimens is affected by dissolution to some degree as on Plate 4 , Figure 2. Plate 4, Figure 4 shows the interior of a split specimen with large rhombohedral crystals interspersed with smaller ones, forming the interior surface (Plate 4, Figure 5). Plate 4, Figure 6, a crosssection (detail of Figure 4), shows a thin outer and a thicker inner layer. No apertures were observed. The average length is $60-65 \mu \mathrm{m}$, the width $50 \mu \mathrm{m}$.

Recorded occurrence: DSDP Site 363, Walvis Ridge, Eastern South Atlantic. Cores 26-34. Infrequent.

Age: Upper Albian, on calcareous nannoplankton (Eiffellithus turriseiffeli Zone), upper Aptian to upper Albian on planktonic foraminifers (approximately Ticinella bejaouensis to Rotalipora apenninica Zone).

\section{Pithonella ef. sphaerica Kaufmann \\ (Plate 4, Figures 7-12; Plate 5, Figures 1-12; Plate 6, Figures 1-12)}

The spherical specimens of fairly variable size, $50-90 \mu \mathrm{m}$ in diameter, often occur in floods in the fine fractions of Cores 26-39. They are here tentatively included in Pithonella sphaerica, a species which like $P$. ovalis was first described from the Senonian part of the Seewerkalk in central Switzerland (see above, under $P$. ovalis). The wall consists of three layers. The outer layer of the Site 363 specimens is affected to various degrees by dissolution. The specimens on Plate 4 , Figures $7-12$ show intact outer layers though individual crystals forming them are corroded. Figures 1-6 on Plate 5 show various degrees of disintegration of the outer layer. In Figures 1 and 2 of Plate 5 the layer is complete. In Figures 3 and 4 of Plate 5 it is partially removed and in Figures 5, 6 it is completely gone. The specimen on Plate 6, Figure 1 has about half of the outer layer disintegrated, that of Plate 6, Figure 4 has only a rudimentary portion remaining, and on Plate 6, Figure 6 no outer layer at all is preserved.

Cross sections, e.g., Plate 5, Figure 11, show the three layers which form the test wall, an outer thin one (uppermost part of Plate 5, Figure (1), a thick intermediate one of not clearly discernible crystal arrangement, and an inner one consisting of mainly distinct large rhombohedral crystals with a short c-axis and up to $6-7 \mu \mathrm{m}$ in diameter (Plate 5, Figures 10-12). The tightly interlocked elongate crystals that form the middle layer seem to have their long axis parallel to the surface. In some specimens their arrangement is radial from a pole which may be marked by a small aperture (Plate 6 , Figures 4,5 ) or they may form a spiral pattern, beginning also from a small aperture as in Figures 6 and 7 of Plate 6. An identical or very similar spiral arrangement of crystals also characterizes specimens of $P$. sphaerica from the Seewerkalk of central Switzerland. An aperture is apparently absent in most $P$. cf. sphaerica of Site 363 . Where present it is variable in size, but usually remains small (Plate 4 , Figures 7, 8, 10, 11: Plate 6, Figures 4-7).

Occasionally two specimens are attached to each other, apparently aperture against aperture (Plate 6, Figures 10-12). Such attachments were found to be frequent in Pithonella thayeri from the Upper Jurassic of the Eastern Indian Ocean Leg 27, Site 261 (Bolli, 1974, pl. 9, fig. 10-12), where they were -interpreted as a possible reproductive stage.

Recorded occurrence: DSDP Site 363, Walvis Ridge, Eastern South Atlantic, Cores 26-39. Frequent to abundant.

Age: Upper Aptian/lower Albian-upper Albian on calcareous nannoplankton (Parhabdolithus angustus to Eiffellithus turriseiffeli Zone), lower Aptian-upper Albian on planktonic foraminifers (Globigerinelloides algeriana to Rotalipora apenninica Zone).

\section{Genus BONETOCARDIELLA Dufour, 1968}

\section{Bonetocardiella ef. conoidea (Bonet)}

(Plate 7, Figures 1-12)

The Site 363 specimens are characterized by rounded to heartshaped tests of $70-80 \mu \mathrm{m}$ diameter and acircular, medium-sized aperture situated in a depression. They are here tentatively included in Bonetocardiella conoidea.

The typical forms originally described by Bonet (1956) and later, e.g., by Andri (1972), are heart-shaped, much like the Site 363 specimen on Plate 7, Figure 2. However, the tests of most specimens of this site are more globular such as those in Figures 1, 3, and 5 of Plate 7. As in Pithonella cf. sphaerica described above, the wall consists of three layers, as shown in the cross-section on Figure 12 of Plate 7. The thin outer layer, whose arrangement of crystals is shown on Figures 4 and 9 of Plate 7, is affected by dissolution to some degree as in the concurring Pithonella species. The middle layer is thicker than the outer one and consists of tightly arranged crystals, similar to Pithonella cf. sphaerica (Plate 5, Figure 11). The inner layer consists of large-sized rhombohedral crystals identical to those in $P$. cf. sphaerica. In contrast to most Pithonella species where apertures are often absent, they are always present in Bonetocardiella. Bonetocardiella cf. conoidea at Site 363 is restricted to the upper Albian.

An Albian to Turonian range was given by Bonet (1956) for Mexico, and an Albian-Cenomanian distribution is quoted by Andri (1972). Cenomanian and Turonian strata are absent at Site 363. A possible extension of the species into these younger stages in the Walvis Ridge are could therefore not be determined.

Recorded occurrence: DSDP Site 363, Walvis Ridge, Eastern South Atlantic, Cores 27-32. Frequent in Cores 27 and 28, scarce in Cores 29-32.

Age: Upper Albian on calcareous nannoplankton (Eiffellithus turriseiffeli Zone), upper Aptian-upper Albian on planktonic foraminifers (approximately Hedbergella trochoidea to approximately Rotalipora ticinensis Zone).

\section{ACKNOWLEDGMENTS}

The author wishes to thank in particular H.E. Franz of the Geology Department, Swiss Federal Institute of Technology, for taking a large number of SEM micrographs for the study of the here described Calcisphaerulidae. J.P. Beckmann from the same institution critically reviewed the manuscript and $U$. Gerber carried out the photographic work for the plates. 


\section{LITERATURE}

Reference is made to Bolli (1974) for papers dealing with Calcisphaerulidae up to 1972. The following papers based on SEM investigations were published since and have some bearing on the Calcisphaerulidae dealt with in this contribution:

Andri and Aubry (1973) discuss and illustrate Upper Cretaceous Pithonella ovalis (Kaufmann) and $P$. perlonga Andri from France. The test shape of $P$. perlonga in cross sections as shown by these authors, and also as earlier illustrated by Andri (1972), strongly resemble that of $P$. krasheninnikovi Bolli.

Bein and Reiss (1976) describe and illustrate Pithonella ovalis (Kaufmann) from Albian to Turonian sediments of Israel. These may be identical or similar to those originally described by Kaufmann and also to those from Site 363 which, like the Israel specimens, have a thicker inner and thinner outer layer.

Rögl (1976) describes Calcisphaerulidae for the first time from the lower Paleocene. Two of his species, Pithonella bollii and P. titanoplax, are here reported from the Walvis Ridge Site 363 lower Paleocene.

From the Netherlands and France, Villain (1975) describes and illustrates Turonian Pithonella sphaerica, and $P$. ovalis, and Bonetocardiella conoidea whose range he gives as Albian to Cenomanian.

\section{REFERENCES}

Andri, E. and Aubry, M.-P., 1973. Recherches sur la microstructure des tests de Pithonella ovalis (Kaufmann) et Pithonella perlonga Andri: Rev. Micropaléontol., v. 16, p. 159-167.

Bein, A. and Reiss, Z., 1976. Cretaceous Pithonella from Israel: Micropaleontology, v. 22, p. 83-91.

Bolli, H.M., 1974. Jurassic and Cretaceous Calcisphaerulidae from DSDP Leg 27, Eastern Indian Ocean. In Veevers, J.J., Heirtzler, J.R., et al., Initial Reports of the Deep Sea Drilling Project, Volume 27: Washington (U.S. Government Printing Office), p. 843-907.

Rögl, F., 1976. Danian Calcisphaerulidae of DSDP Leg 35, Site 323, Southeast Pacific Ocean. In Hollister, C.D., Craddock, C., et al., Initial Reports of the Deep Sea Drilling Project, Volume 35: Washington (U.S. Government Printing Office), p. 701-711.

Villain, J.M., 1975. "Calcisphaerulidae" (incertae sedis) du Crétacé supérieur du Limbourg (Pays-Bas), et d'autres régions: Paleontographica, Abt. A., v. 149, p. 193-242. 


\section{PLATE 1}

Figures 1-6 Pithonella cf. bollii Rögl.

1. Specimen without aperture. Sample 363-18-1, $70-72 \mathrm{~cm}, \times 500$, C 33949.

2. Detail of surface of 1 , showing strongly corroded rhombohedral crystals, $\times 2500$.

3. Specimen with very small aperture. Sample $363-18-1,52-54 \mathrm{~cm}, \times 500$, C 33950.

4. Specimen with large circular aperture. Sample 363-18-1, 98-100 cm, ×500, C 33951.

5. Detail of apertural rim of 4 , showing an inner layer composed of smaller crystals and a thicker outer layer of larger crystals, $\times 2500$.

6. Detail of surface of 4 , showing strongly corroded rhombohedral crystals, $\times 2500$.

Figures 7-12 Pithonella titanoplax Rögl.

7. Side view of specimen with very large aperture. Sample 363-18-1, $52-54 \mathrm{~cm} . \times 500, \mathrm{C}$ 33952.

8. Detail of apertural rim of 7 , showing inner and outer wall layer of about equal thickness, $\times 2500$.

9. Detail of surface of 7 , showing the criss-cross pattern of the fairly loosely arranged tabular crystals, $\times 2500$.

10. Oblique apertural view of specimen with very large aperture. Its interior is filled with coccoliths including Cruciplacolithus tenuis, an index form for the lower Paleocene. The two layers forming the wall are clearly visible at the upper right of the aperture. Sample 363$18-1,52-54 \mathrm{~cm}, \times 500$, C 33953.

11. Enlargement of apertural area of $10, \times 1000$.

12. Detail of surface of 10 , showing fairly loosely arranged crystals, $\times 2500$. 


\section{PLATE 1}
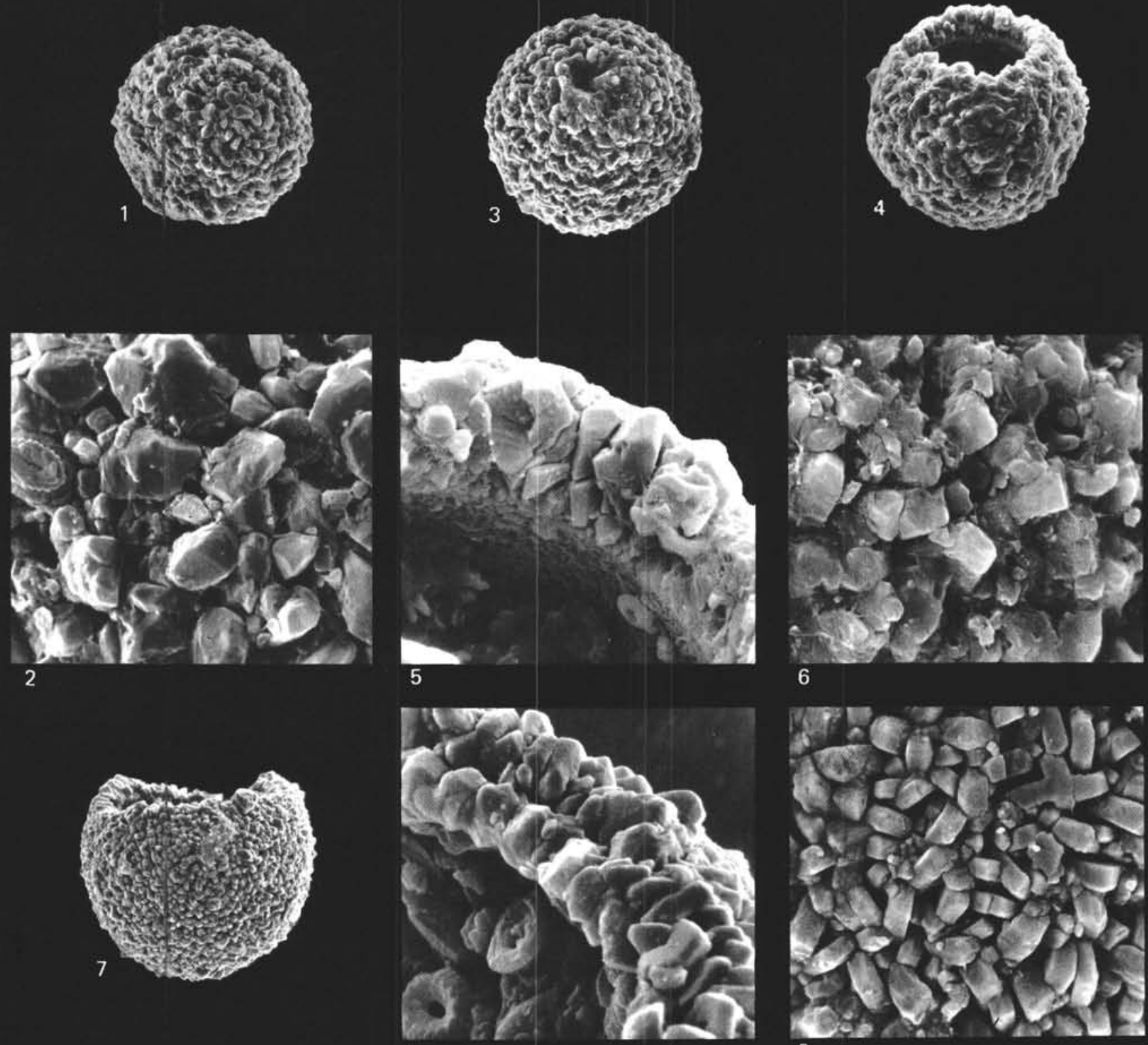

8

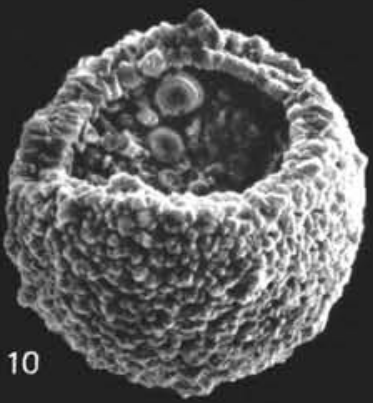

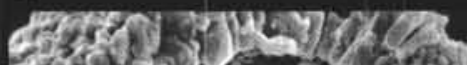

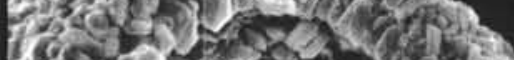

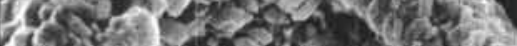

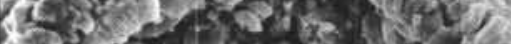

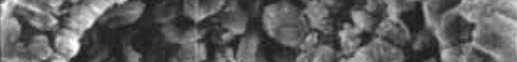

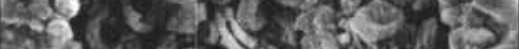

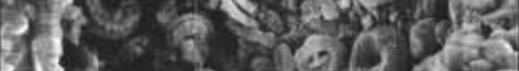

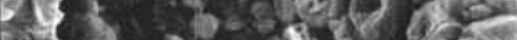

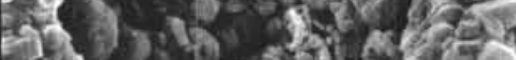

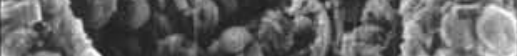

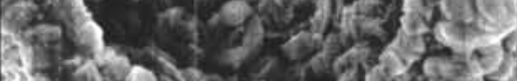
ats

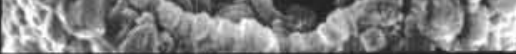

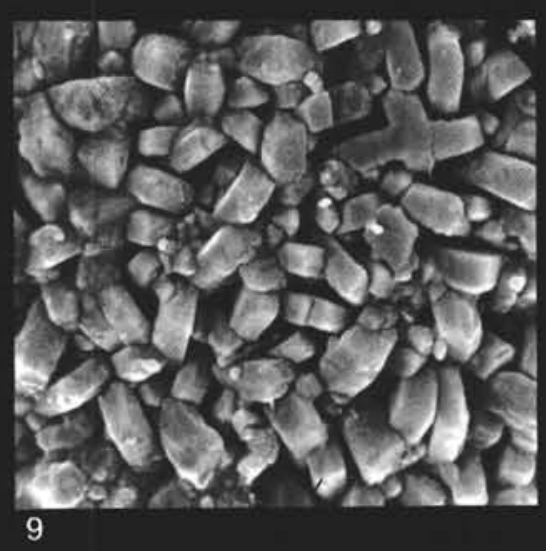

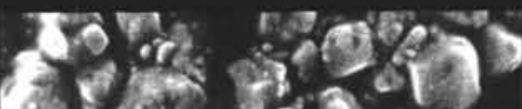

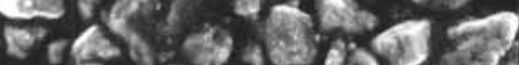

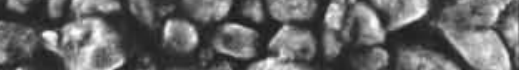

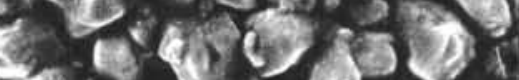

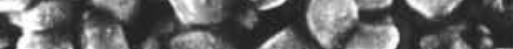

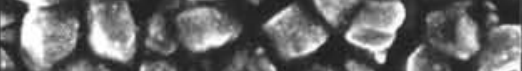

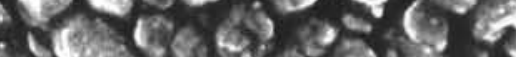

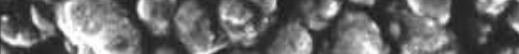

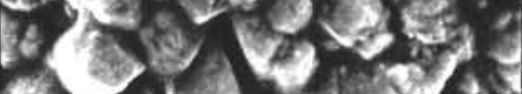
28 


\section{PLATE 2}

Figures 1-12 Pithonella cooki Bolli.

1. Side view of only slightly elongate specimen without aperture. Sample 363-20-1, 58-60 cm, $\times 500$, C 33954 .

2. Side view of moderately elongate specimen. Sample 363-18-2, 136-138 cm, ×500, C 33955.

3. Oblique view of specimen 2 with fairly large circular aperture, $\times 500$.

4. Detail of apertural rim showing inner and outer layer, $\times 2500$.

5 . Side view of moderately elongate specimen. Sample 363-19-2, 58-60 cm, ×500, C 33956.

6. Surface of 5, showing loosely and irregularly arranged crystals, $\times 2500$.

7. Oblique apertural view of a slightly elongate specimen with the outer layer partially removed in the apertural area, showing the outer surface of the inner layer. Sample 36320-1, 58-60 cm, ×500, C 33957.

8. Detail of apertural area of $7, \times 2500$.

9. Side view of moderately elongate specimen with asymmetrically positioned aperture at upper end. Sample 363-21-1, 58-60 cm, $\times 500$, C 33958.

10. Side view of elongate specimen. Sample 36320-1, 58-60 cm, ×500, C 33959.

11. Side view of distinctly elongate specimen with circular aperture. Sample 363-21-1, 58-60 cm, $\times 500$, C 33960.

12. Apertural area of 11 , showing some large crystals of the inner layer surrounded by smaller ones of the outer layer, $\times 2500$. 
PLATE 2

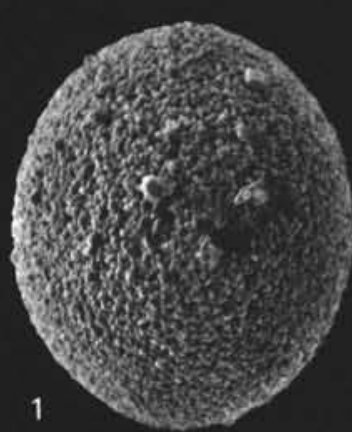

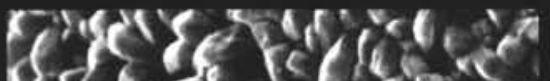

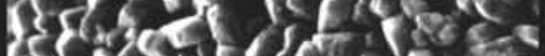
Cec)

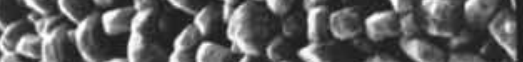
cercestict

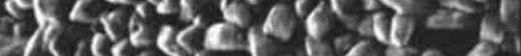

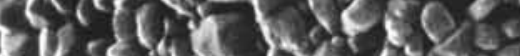

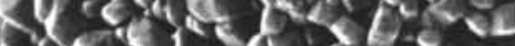

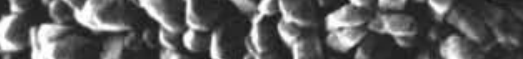

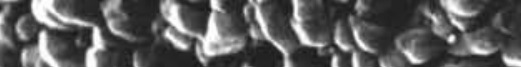

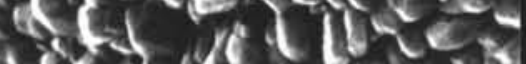
6
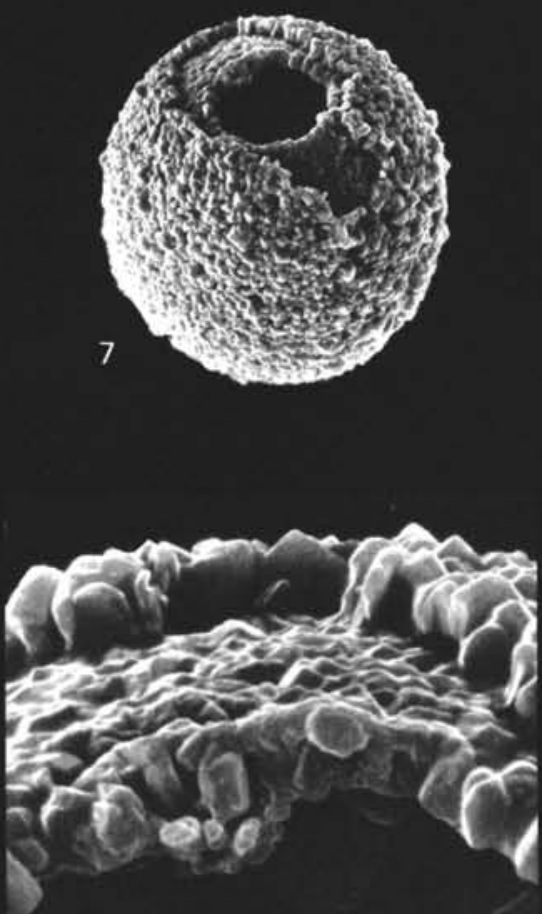

8
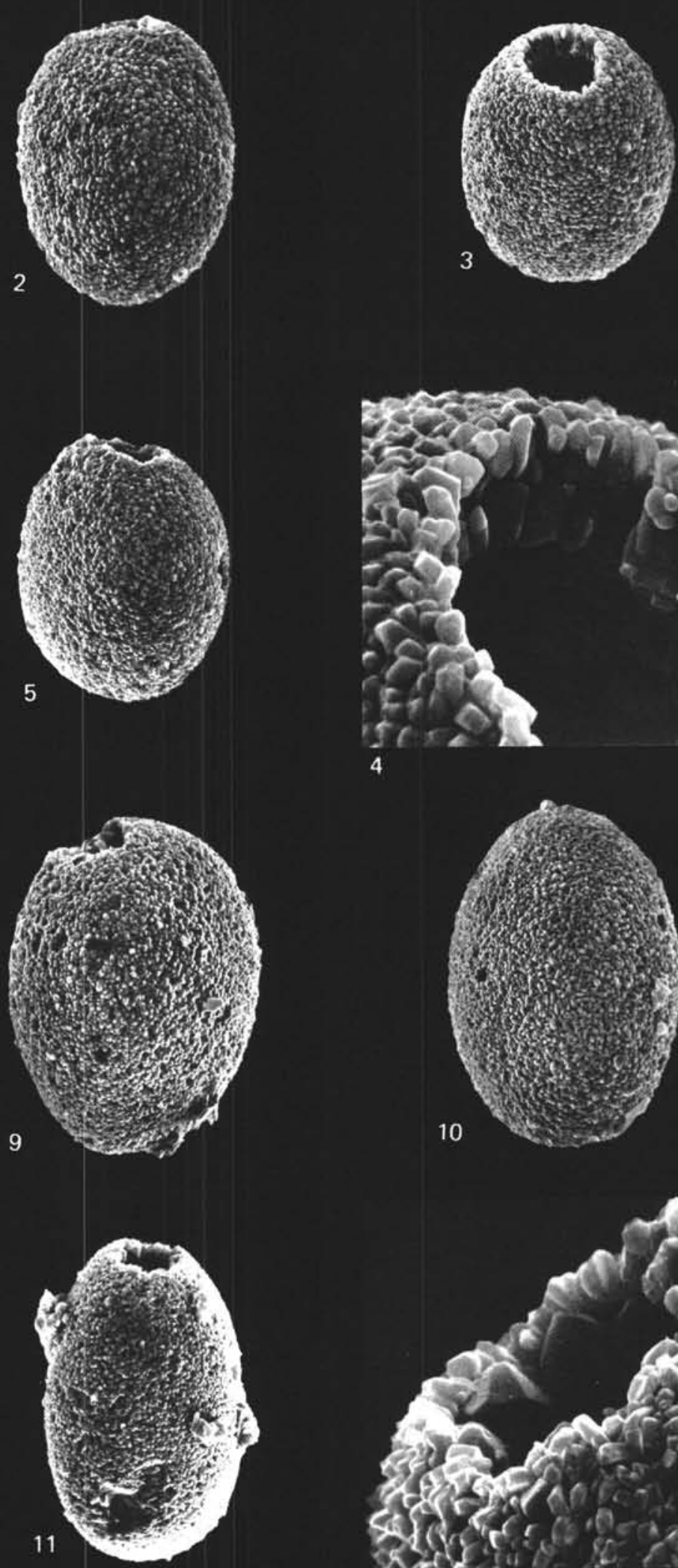
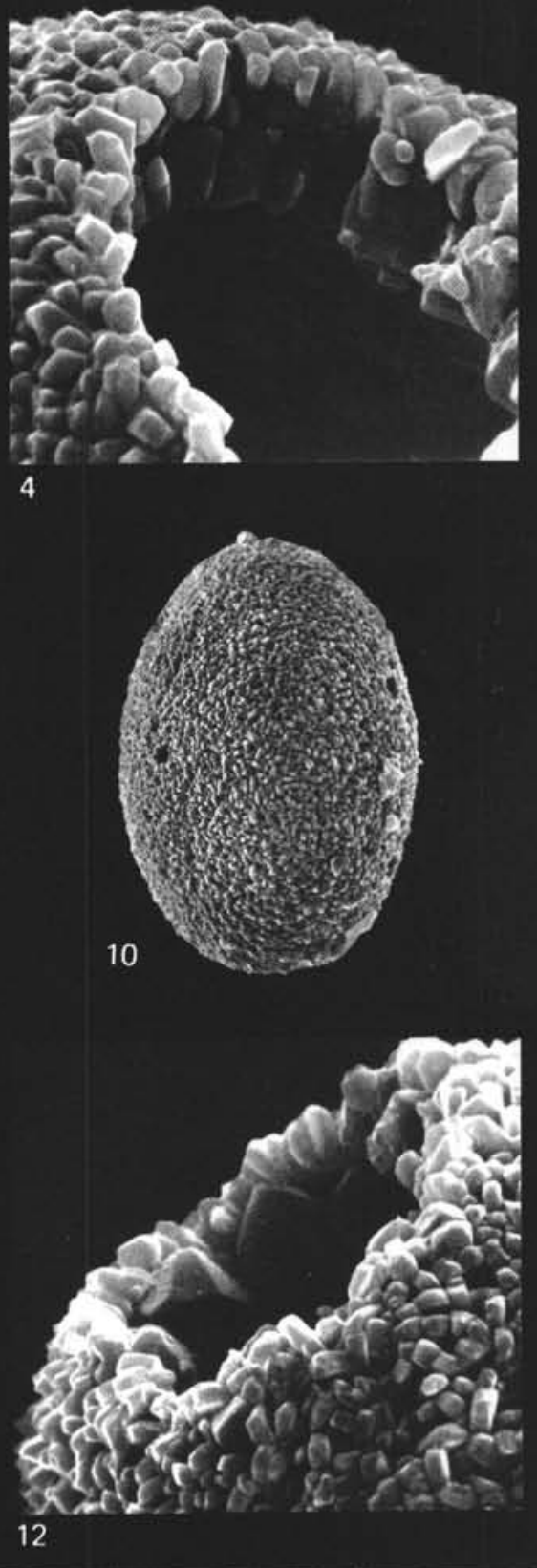


\section{PLATE 3}

Figures 1-12 Pithonella krasheninnikovi Bolli.

1. Side view of slender specimen without aperture. Sample 363-20-1, 58-60 cm, $\times 500, C$ 33961.

2. Side view of specimen with asymmetrically positioned aperture at upper end. Sample 36321-1, 58-60, ×500, C 33962 .

3. Detail of surface of 2 , showing loosely and irregularly arranged crystals, $\times 2500$.

4. Apertural area of $2, \times 1000$.

5. Side view of fairly wide specimen with circular terminal aperture. Some corrosion is visible on the surface. Sample 363-21-1, 58-60 cm, $\times 500$, C 33963 .

6. Detail of surface of 5. Several of the large rhombohedral crystals of the inner layer show through the very loosely and partially dissolved smaller tabular crystals of the outer layer, $\times 2500$.

7. Detail of apertural area of 5 , clearly showing the large rhombohedral crystals of the inner, and the smaller tabular crystals of the outer layer, $\times 2500$.

8. Side view of specimen without aperture and outer layer completely dissolved. Sample 36322-1, 77-79 cm, $\times 500$, C 33964.

9. Detail of surface of 8 . The crystal surfaces of the inner layer are also affected by incipient dissolution. A coccolith fragment embedded in a crystal is visible below the center of the photograph and immediately to the right of the small rhombohedral crystal, $\times 2500$.

10. Side view of specimen with large circular terminal aperture and with outer layer dissolved. Sample 363-22-1, 77-79 cm, $\times 500$, C 33965.

11. Oblique view of specimen with large circular terminal aperture and with outer layer dissolved. Sample 363-22-1, 77-79 cm, $\times 500$, C 33966.

12. Detail of apertural rim of 11 , consisting of inner layer only, $\times 2500$. 
PLATE 3

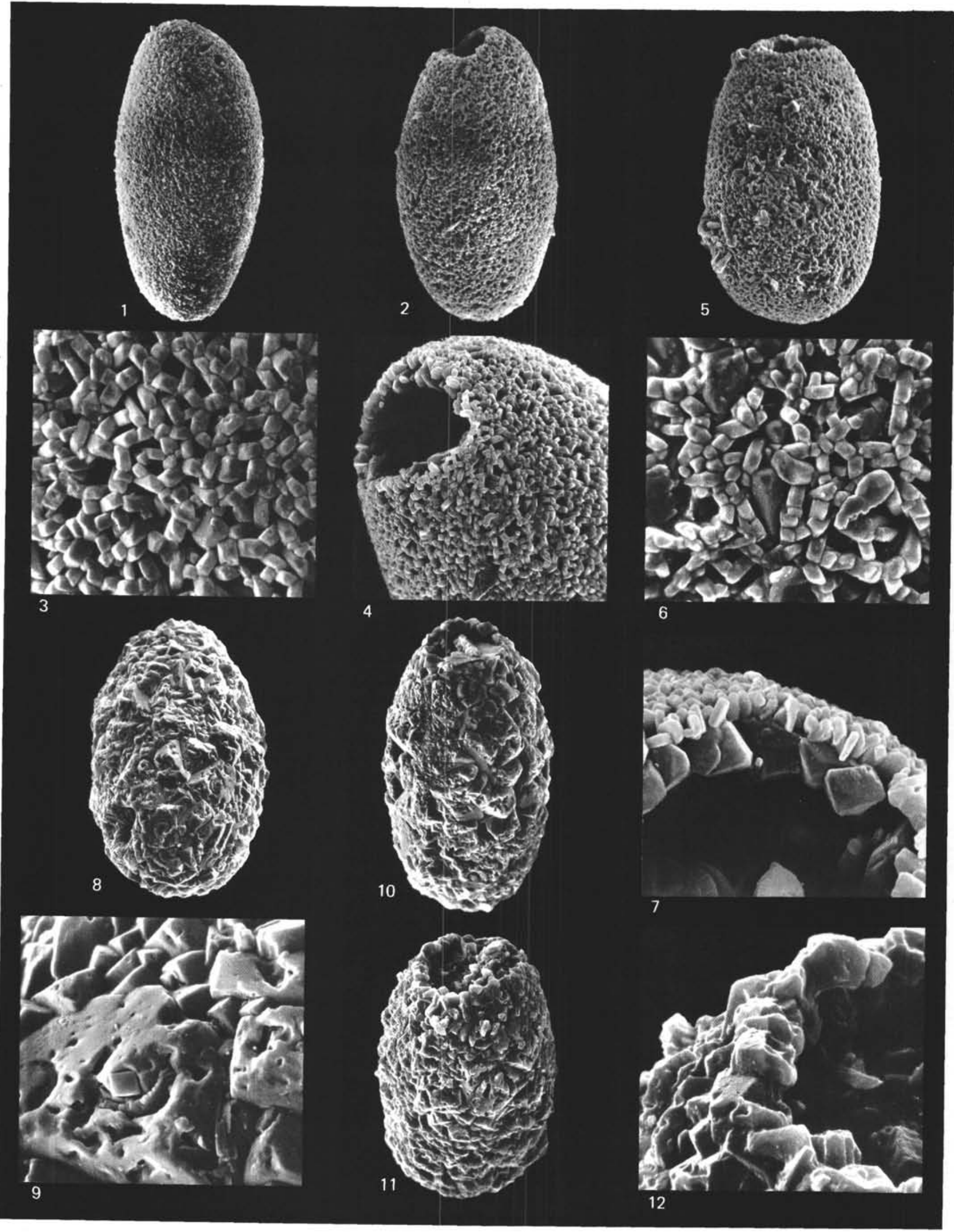




\section{PLATE 4}

Figures 1-6 Pithonella cf. ovalis (Kaufmann).

1. Side view of specimen without aperture. Sample 363-26, CC, ×500, C 33967.

2. Detail of surface of 1 , showing individual crystals affected by corrosion, $\times 2500$.

3. Side view of specimen without aperture, surface affected by dissolution. Sample 36326, CC, $\times 500, C 33968$.

4. Split specimen, showing surface of inner side and cross-section of wall. Sample 363-26, CC, $\times 500$, C 33969.

5. Detail of inner surface of 4 , showing loosely arranged large rhombohedral crystals, with interspaces filled with smaller ones, $\times 2500$.

6. Detail of wall section of 4 , showing outer and inner layer, $\times 2500$.

Figures 7-12 Pithonella cf. sphaerica (Kaufmann).

7. Apertural view of small specimen. Sample 363-26, CC, $\times 500$, C 33970.

8. Detail of apertural area of $7, \times 1500$.

9. Medium sized specimen without aperture. Sample 363-26, CC, $\times 500$, C 33971.

10. Medium sized specimen with very small aperture. Sample 363-26, CC, ×500, C 33972.

11. Apertural area of $10, \times 1500$.

12. Detail of surface of 10 , showing corroded individual crystals, $\times 2500$. 

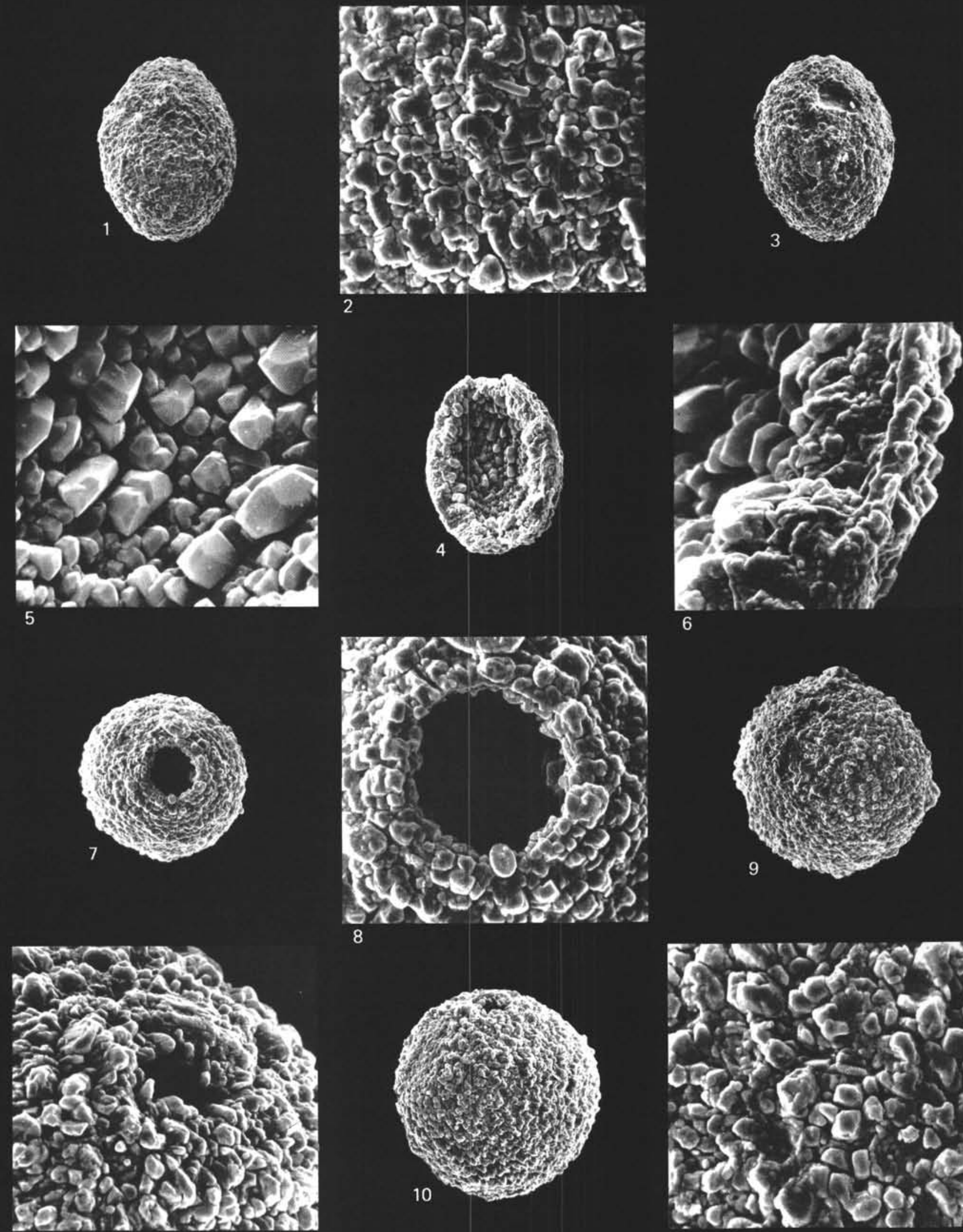


\section{PLATE 5}

Figures 1-12 Pithonella cf. sphaerica (Kaufmann).

1. Large specimen with outer layer preserved but corroded. Sample 363-29-1, 71-73 cm, $\times 500$, C 33973.

2. Detail of surface of $1, \times 2500$.

3. Large specimen with outer layer partially dissolved. Sample 363-29-1, 71-73 cm, $\times 500$, C 33974.

4. Detail of surface of 3 , showing outer layer preserved only in upper left part of photograph, $\times 2500$.

5. Large specimen with outer layer totally dissolved and part of middle layer destroyed. Sample 363-32-4, 72-78 cm, ×500, C 33975.

6. Surface detail of $5, \times 2500$.

7. Specimen with large aperture, wall strongly affected by dissolution. Sample 363-32-4, 72$78 \mathrm{~cm}, \times 500$, C 33976 .

8. Detail of surface of 7 , upper part of photograph shows outer layer, lower part the middle layer, $\times 2500$.

9. Split specimen showing inner surface and cross-section of wall. Sample 363-32-4, 72-78 $\mathrm{cm}, \times 500$, C 33977.

10. Detail of 9 showing cross-section of wall and large rhombohedral crystals of inner layer, $\times 2500$.

11. Detail of a split specimen showing crosssection of wall; from top to bottom of photograph are visible the thin outer layer, the thick middle layer, and the inner layer consisting of large rhombohedral crystals. Sample 363-32-4, $72-78 \mathrm{~cm}, \times 2500$, C 33978 .

12. Rhombohedral crystals of inner layer of same specimen as $11, \times 2500$. 

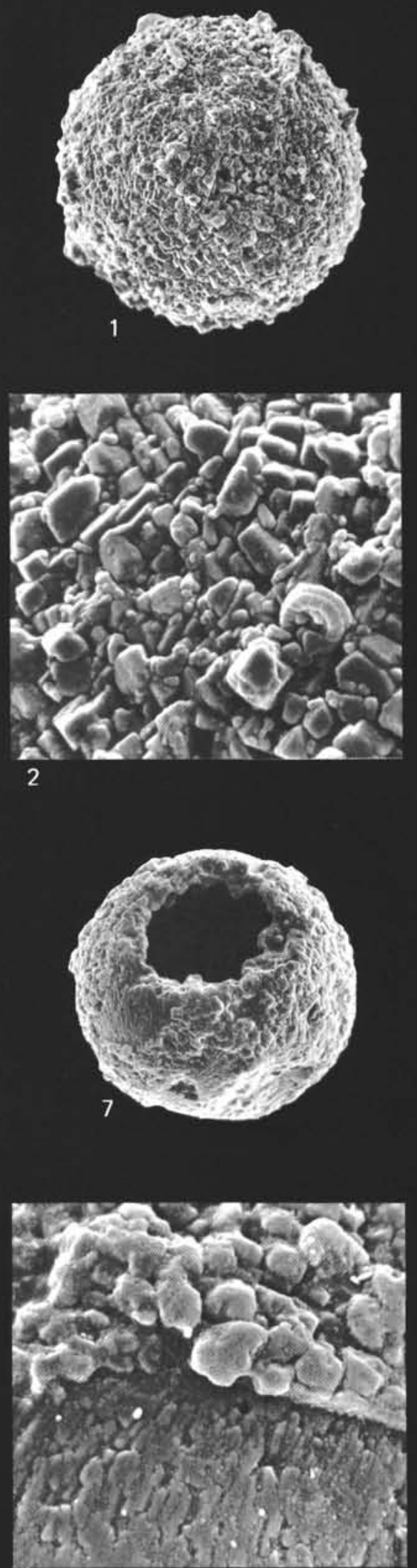
8
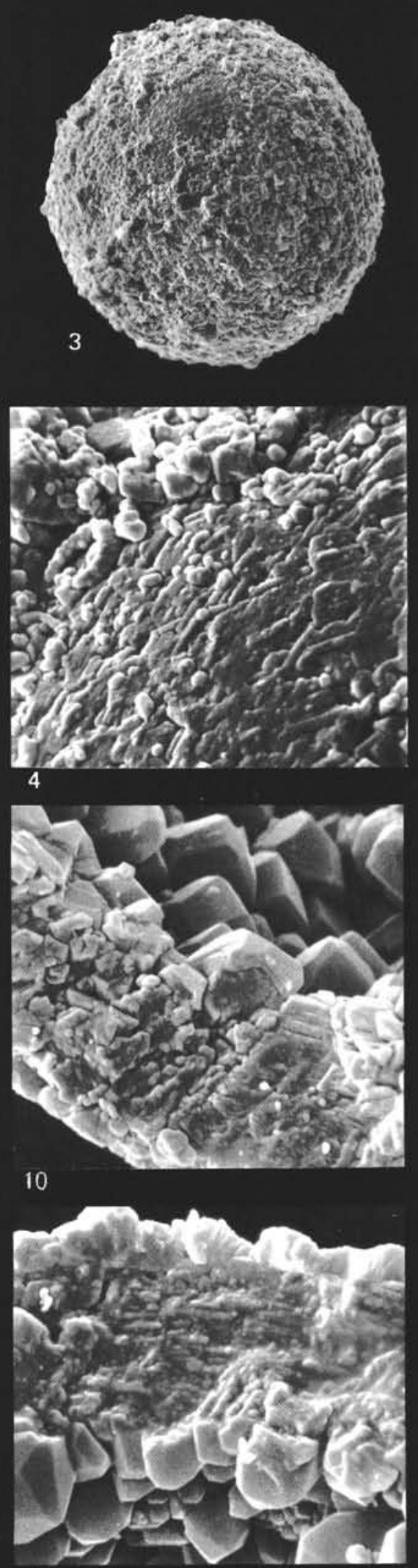

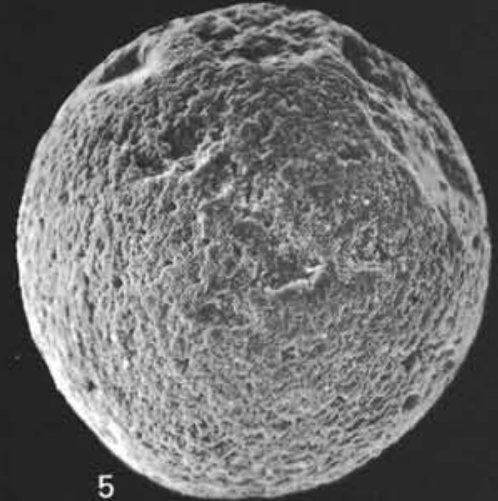

P.

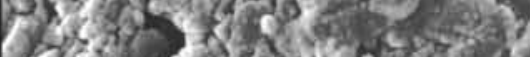

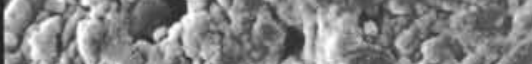

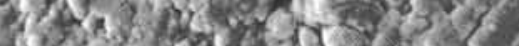

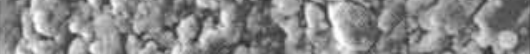

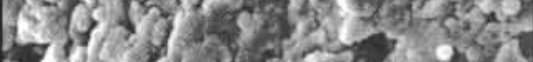

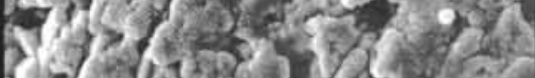

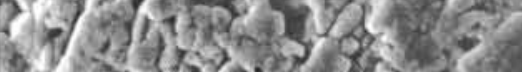

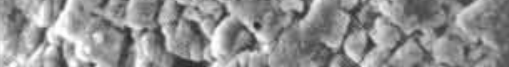

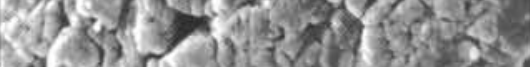
6
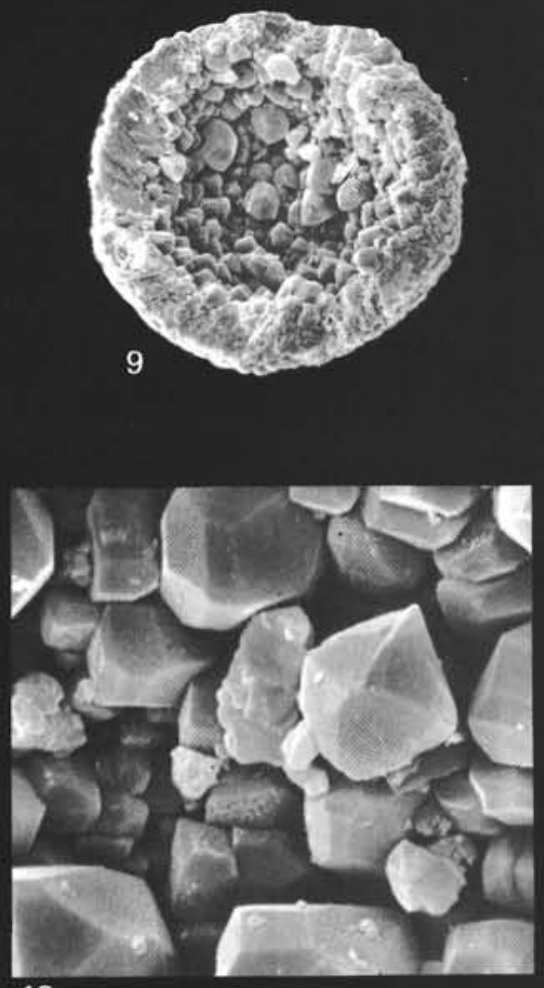
12 


\section{PLATE 6}

Figures 1-12 Pithonella cf. sphaerica (Kaufmann).

. 1. Small specimen with the outer layer on left side missing. Sample $363-37-4,71-73 \mathrm{~cm}$, $\times 500$, C 33979 .

2. Detail of surface of 1 , in center and right side of photograph part of outer layer preserved, $\times 2500$.

3. Detail of outer layer of 1 , showing corrosion of individual crystals, $\times 2500$.

4. Specimen with only a small portion of the outer layer remaining on top left. A very small aperture is visible in the center from where the elongate and tightly interlocked crystals of the middle layer radiate. Sample 363-34-1, 116$118 \mathrm{~cm}, \times 800$. C 33980 .

5. Detail of apertural area of $4, \times 1000$.

6. Specimen with no outer layer left. A small aperture is visible between center and top of specimen, from where the elongate and tightly interlocked crystals of the middle layer form a spiral pattern. Sample $363-32$, CC, $\times 500, C$ 33981.

7. Detail of apertural area of $6, \times 2500$.

8. Specimen with very large aperture, possibly a broken specimen. Sample 363-34-1, 116-118 $\mathrm{cm}, \times 500$, C 33982 .

9. Detail of interior surface of $8, \times 2500$.

10. Two specimens attached to each other. Outer surfaces showing strong corrosion. Sample 363-34-1, 116-118 cm, ×400, C 33983.

11. Two specimens attached to each other. Outer surface of lower specimen showing corrosion. The outer layer of the upper specimen is completely dissolved. Sample 363-34-1, 116-118 $\mathrm{cm}, \times 400$, C 33984.

12. Detail of area where the two specimens of 11 are attached to each other, $\times 1000$. 


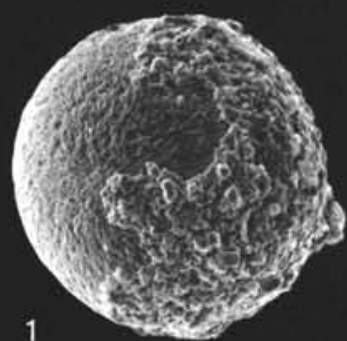

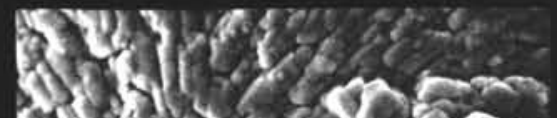

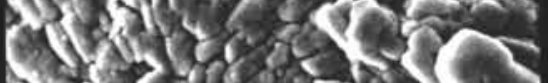

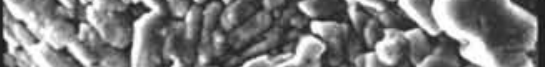

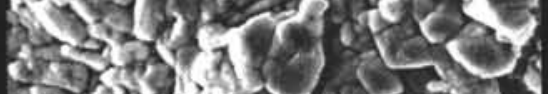

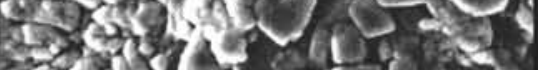

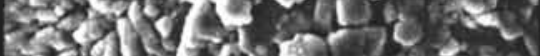

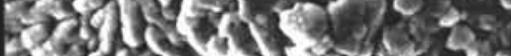

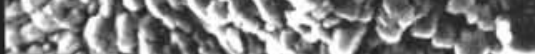

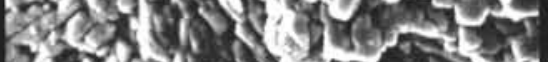
3 sitil

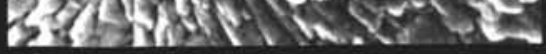
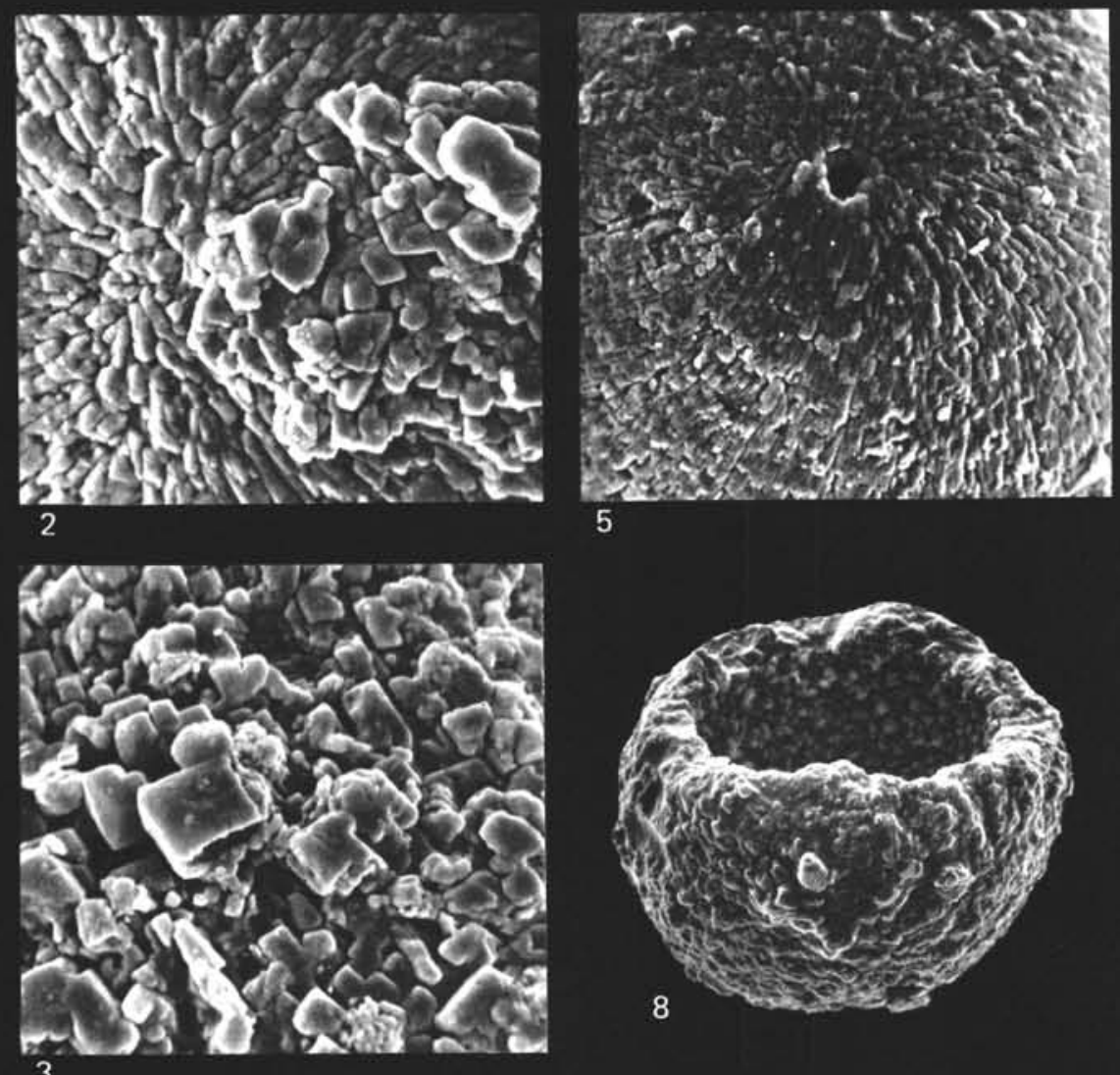
5
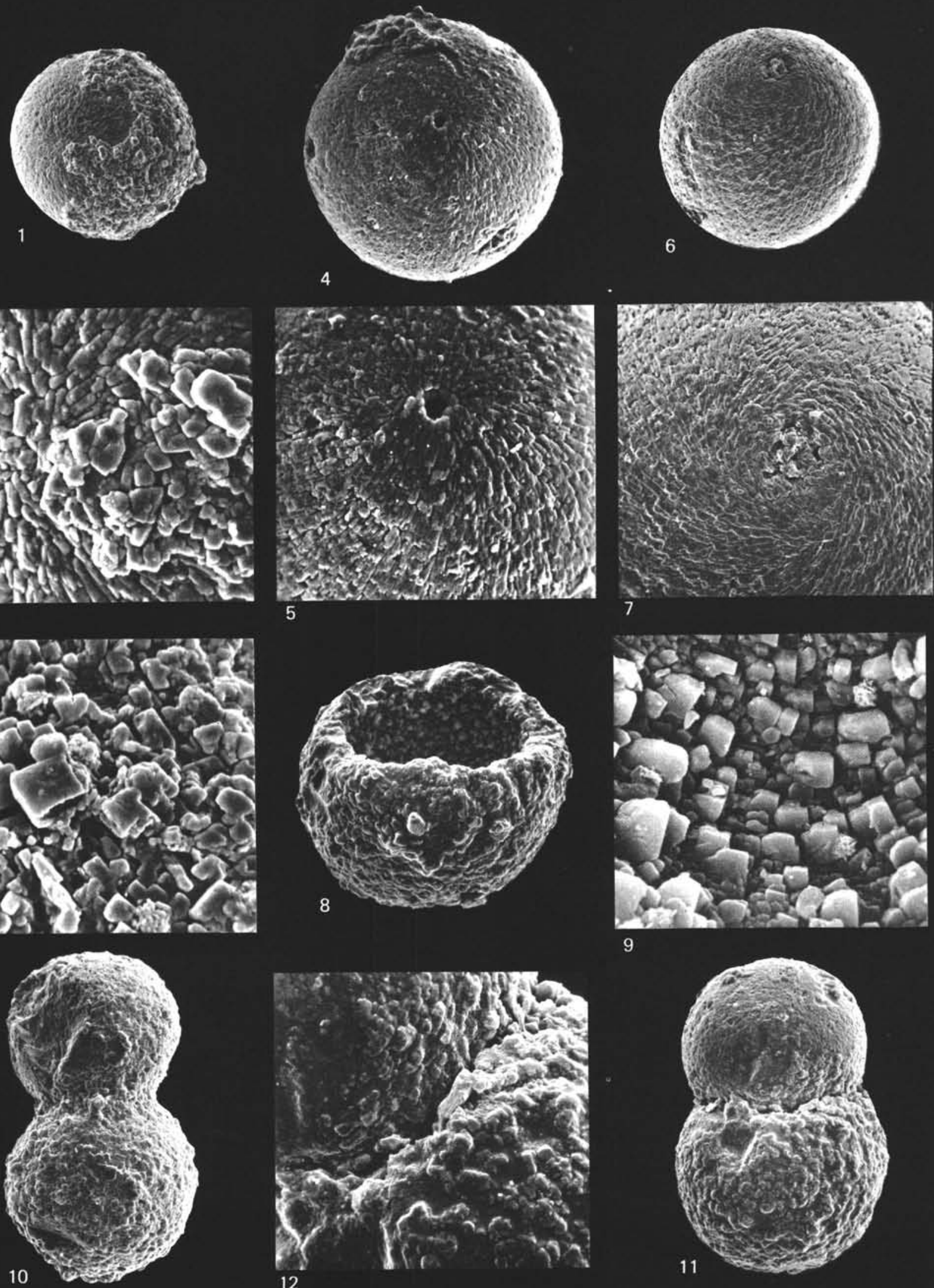


\section{PLATE 7}

Figures 1-12 Bonetocardiella cf. conoidea (Bonet).

1. Oblique side view of specimen, apertural position in distinct depression clearly visible. Sample 363-27-1, 44-46 cm, ×500, C 33985.

2. Specimen 1 in side view, showing heart-shaped form, $\times 500$.

3. Oblique side view of specimen with aperture visible. Sample 363-28-1, 107-109 cm, $\times 500, C$ 33986.

4. Detail of surface of 3 , showing the tightly interlocked but somewhat corroded crystals, $\times 2500$.

5. Oblique apertural view of specimen. Sample $363-27-1,44-46 \mathrm{~cm}, \times 500, \mathrm{C} 33987$.

6. Detail of apertural area of $5, \times 2500$.

7. Apertural view of specimen with very large aperture. Sample 363-28-1, 107-109 cm, ×500, C 33988.

8. Detail of apertural area of $8, \times 2500$.

9. Detail of surface of outer layer with fairly well preserved, tightly interlocked crystals. Sample 363-28-1, 107-109 cm, ×2500, C 33989.

10. Split specimen showing inner surface and cross section of test well. Sample 363-28-1, 107-109 cm, ×500, C 33990 .

11. Rhombohedral crystals of inner layer of 10 , $\times 2500$.

12. Detail of wall cross-section of 10. In upper part of photograph the large rhombohedral crystals of inner layer, below the indistinct middle layer and (light colored) thin outer layer, $\times 2500$. 
PLATE 7
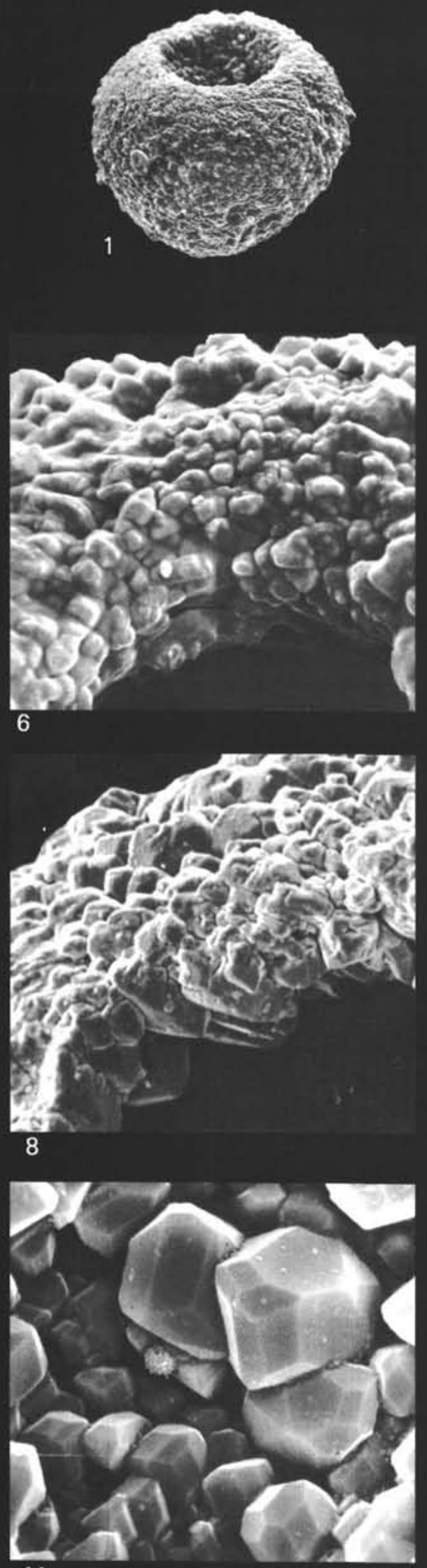
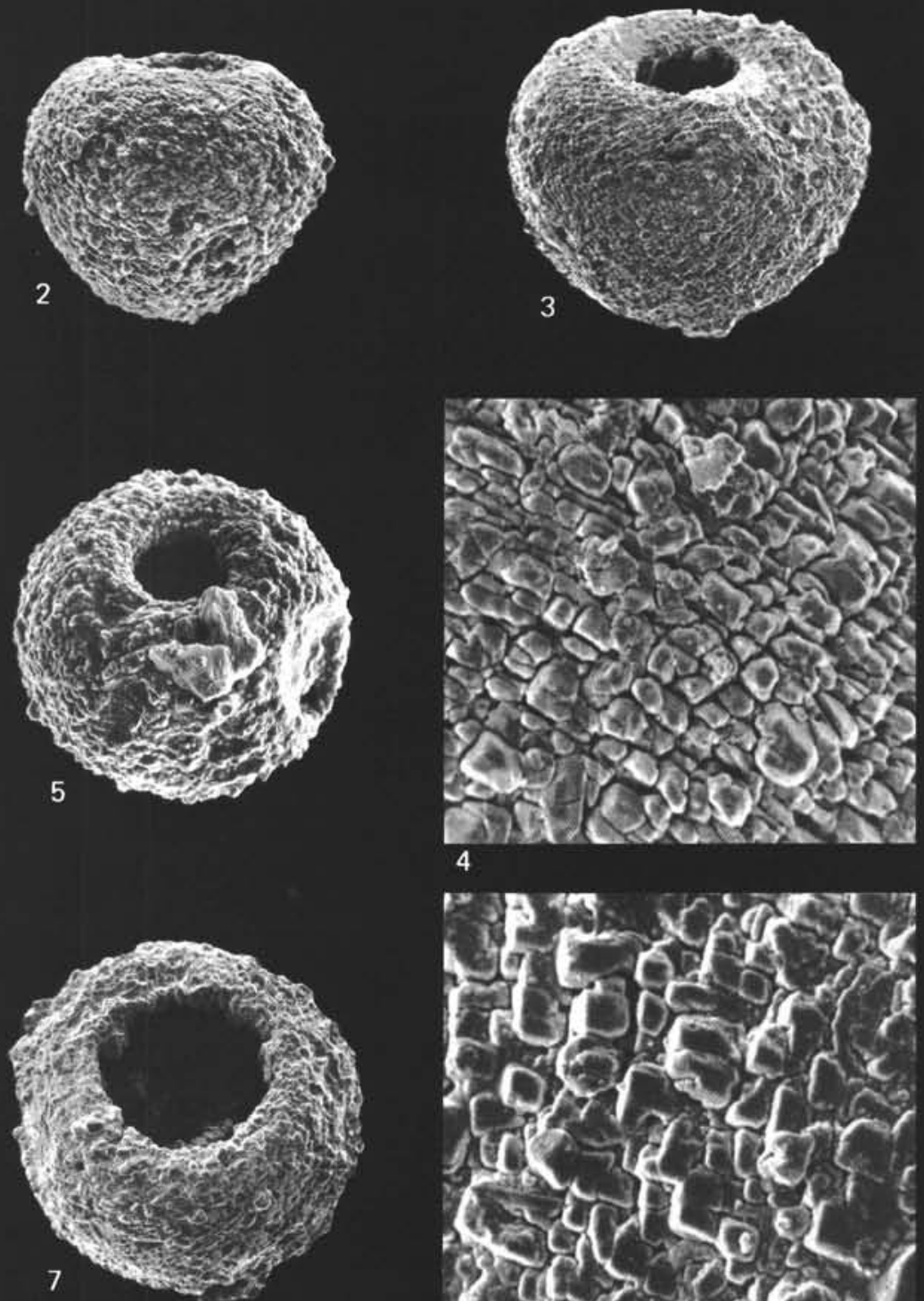
4
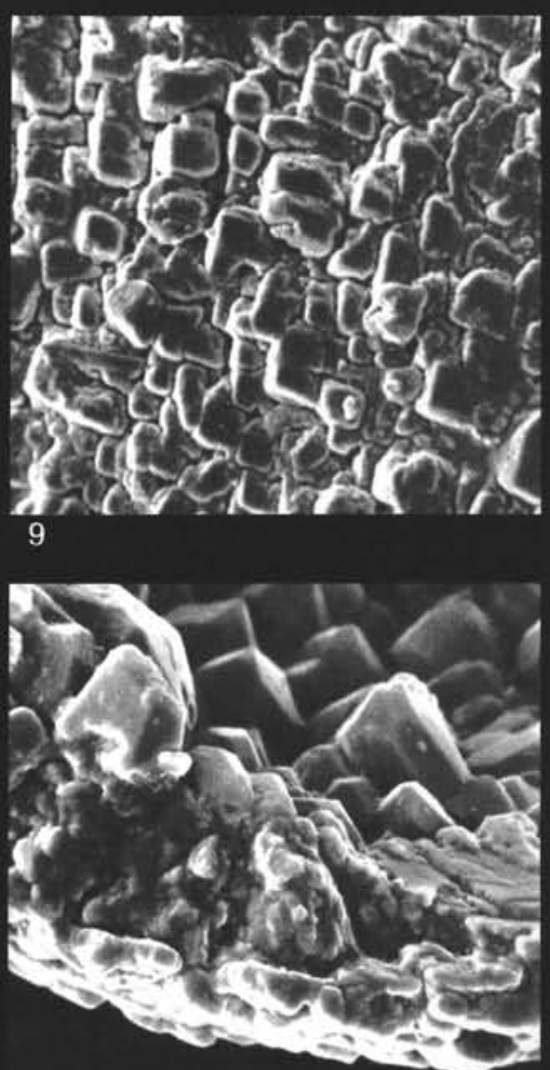